University of Nebraska - Lincoln

DigitalCommons@University of Nebraska - Lincoln

3-2006

\title{
Leisure Time in Japan: How Much and for Whom?
}

Scott M. Fuess Jr.

University of Nebraska-Lincoln, SFUESS1@UNL.EDU

Follow this and additional works at: https://digitalcommons.unl.edu/econfacpub

Part of the Economics Commons

Fuess, Scott M. Jr., "Leisure Time in Japan: How Much and for Whom?" (2006). Economics Department Faculty Publications. 38.

https://digitalcommons.unl.edu/econfacpub/38

This Article is brought to you for free and open access by the Economics Department at DigitalCommons@University of Nebraska - Lincoln. It has been accepted for inclusion in Economics Department Faculty Publications by an authorized administrator of DigitalCommons@University of Nebraska - Lincoln. 


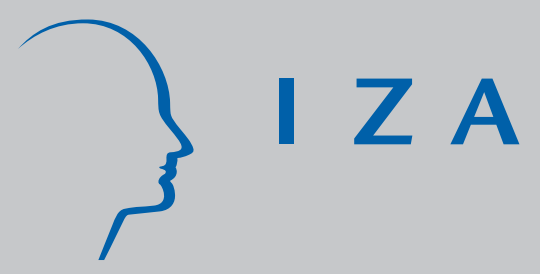

IZADP No. 2002

Leisure Time in Japan: How Much and for Whom?

Scott M. Fuess, J r.

March 2006 


\title{
Leisure Time in Japan: How Much and for Whom?
}

\author{
Scott M. Fuess, Jr. \\ University of Nebraska-Lincoln \\ and IZA Bonn
}

Discussion Paper No. 2002

March 2006

\author{
IZA \\ P.O. Box 7240 \\ 53072 Bonn \\ Germany \\ Phone: +49-228-3894-0 \\ Fax: +49-228-3894-180 \\ Email: iza@iza.org
}

\begin{abstract}
Any opinions expressed here are those of the author(s) and not those of the institute. Research disseminated by IZA may include views on policy, but the institute itself takes no institutional policy positions.

The Institute for the Study of Labor (IZA) in Bonn is a local and virtual international research center and a place of communication between science, politics and business. IZA is an independent nonprofit company supported by Deutsche Post World Net. The center is associated with the University of Bonn and offers a stimulating research environment through its research networks, research support, and visitors and doctoral programs. IZA engages in (i) original and internationally competitive research in all fields of labor economics, (ii) development of policy concepts, and (iii) dissemination of research results and concepts to the interested public.
\end{abstract}

IZA Discussion Papers often represent preliminary work and are circulated to encourage discussion. Citation of such a paper should account for its provisional character. A revised version may be available directly from the author. 
IZA Discussion Paper No. 2002

March 2006

\section{ABSTRACT}

\section{Leisure Time in Japan: How Much and for Whom?}

Japan is famous for long working hours. For decades the Japanese government has tried to influence how people spend their free time. In 5-yearly surveys since 1986, the government has surveyed "quality of life" by gauging how much time people spend daily in various "noneconomic" activities. Using results from the 1986, 1991, 1996, and 2001 surveys, this study determines whether time spent daily on leisure activities has actually changed. Controlling for labor market forces, in recent years Japanese adults have not experienced more leisure time overall. They have increased time spent, one hour per week, in media-oriented leisure; this increase, however, comes at the expense of more outgoing amusements like hobbies, playing sports, or socializing with friends. There is a significant gender gap for leisure time. Shorter work schedules do encourage a more active leisure lifestyle. Leisure is directly related to regular income, but is stifled by bonus pay.

JEL Classification: J20, J22, J40

Keywords: $\quad$ time allocation, leisure time and working hours, country studies, Japan

Corresponding author:

Scott M. Fuess, Jr.

Department of Economics

College of Business Administration

University of Nebraska

P.O. Box 880489

Lincoln, NE 68588-0489

USA

Email: sfuess1@unl.edu 


\section{Introduction}

Japan is renowned for especially long working hours. The Japanese language even has a particular term for "death from overwork" (karoshi). Moreover, the country is known for a particularly stressful living conditions: workers face long commuting times and live in cramped housing. Although nominally rich, the "emptiness of Japanese affluence” has been documented and studied extensively (for example, see McCormack, 1996). ${ }^{1}$ So it is not surprising that in recent years the national lifestyle (seikatsu) has become an important issue in the country.

As noted by Leheny (2003), the heart of the debate has been the infamous (and foreign, ostensibly European) jibe that Japan is a nation of "workaholics living in rabbit hutches.” Indeed, that jibe has been cited in "practically every Japanese-language work on leisure and lifestyle issues since it was originally uttered” (Leheny, p. 107).

For decades the Japanese government has formulated policies to shape leisure activities, aiming to influence peoples' free time and how they enjoy that time. Since the early 1990s the government has sought to improve quality of life, trying to transform the country into a "lifestyle superpower” (seikatsu taikoku).

In a recent account, Leheny (2003) documented in detail various changes in government leisure policies. ${ }^{2}$ There have been efforts to provide more free time for workers and students. Schools and business have been encouraged to adopt five-day weeks (dropping Saturday as a school/work day). New public holidays have been established; Monday holidays have created three-day weekends. In 1994 the government announced a desire to reduce working hours across the country, setting a target of 150 regular working hours per month by 1996 . There also have been policies to encourage the building of museums, resorts, and theme parks.

Every five years the Japanese government conducts surveys on "Time Use and Leisure Activities.” The survey tracks how people spend time in their daily lives. Since 1986 the survey has tried to document "quality of life” by gauging how much time people spend daily in various “non-economic” activities. Using results from the 1986, 1991, 1996, and 2001 surveys, this 
study determines whether time spent daily on leisure activities has actually changed. Despite considerable talk about building a lifestyle superpower, despite catch phrases like "wealthy and happy society” (yutaka na shakai), how has leisure time changed in daily living, if at all? Has time been re-allocated among leisure activities? In analyzing these questions, I compare the experiences of men and women. I also examine whether leisure is more likely to be taken by high-income workers or younger, lower income individuals.

\section{Japanese Surveys of Time Use: Leisure and Work}

In 2001 the Japanese government surveyed 77,000 households selected from 6,440 different enumeration districts across the country. ${ }^{3}$ Overall, approximately 200,000 persons (aged 10 years and older) were surveyed. Specifically, two consecutive days within the October 13-21 period were designated for each enumeration district; individuals from that district kept detailed diaries about their time use over the two-day span. The 1996, 1991, and 1986 surveys were conducted similarly. ${ }^{4}$

In surveys individuals kept diaries, recording how much time was allocated to each of twenty different activities. Among those activities were a number of "leisure" pursuits. These leisure activities include time spent (1) watching television, listening to radio, reading newspapers or magazines (“media” activities), (2) studying or researching for self-improvement (not regular schoolwork), (3) pursuing hobbies and amusements, (4) playing sports, (5) volunteering and other social causes, and (6) socializing.

Individual responses were aggregated by different age groups. There are averages for males aged 10-14, 15-19, 20-24, . . , 60-64, 65-69, and 70+. Similarly, averages by age group are reported for females.

For each of the six categories of leisure activity, two pieces of information are reported for each age group. First is the participation rate, which is the fraction of respondents in the group who engaged in the leisure activity during the survey period. Second is the time spent per 
day by those who engaged in the leisure activity. The product of these two bits of information yields the expected value of time spent in the leisure activity. Summing the expected values of time spent in each leisure activity, I calculated overall expected leisure time

While the "Time Use” surveys track leisure activities for males and females in various age groups, Japan’s Ministry of Labour surveys the labor force annually to gauge working times. Specifically, the ministry tracks duration of service, regularly scheduled working hours, nonscheduled working hours, monthly contractual earnings, annual bonuses, labor force participation, and unemployment. Individual responses are aggregated for males and for females by twelve age groups: <17, 18-19, 20-24, . ., 60-64, and 65+.

Each year’s “work” survey provides twenty-four observations: averages for twelve different age groups of males and females. ${ }^{5}$ Thus, there are 96 observations on working time that can be matched with data on leisure activities. So for 1986, 1991, 1996, and 2001, I merged the results of the "work" and "Time Use” surveys, which allows me to analyze the relationship between leisure activities and various aspects of working life. ${ }^{6}$

\section{Leisure Activities}

In Japan Sunday traditionally has been a "day off” from school and office; the other days of the week have been work days. Consequently, the "Time Use” surveys distinguish between leisure activities on Sundays versus those of the other weekdays.

Table 1 presents figures for expected leisure time per weekday. Averaging across the 96 observations, it can be seen that expected weekday leisure time is 3.4 hours. Far and away, media activities account for most of the leisure time (2.1 hours per day, 62.3\% of leisure time). Excluding these passive, media activities (time spent watching television, listening to radio, reading newspapers or magazines), expected leisure is only 1.3 hours per weekday. The most common "active" pursuits are hobbies and socializing, with roughly a half-hour per day for hobbies (0.5 hours) and little more than 20 minutes for socializing (0.4 hours). "Improving” 
activities (volunteering and studying for self-improvement) account for 18 minutes per day (0.3 hours); the expected time playing sports is not even 10 minutes ( 0.15 hours).

Whereas Japanese people can expect roughly 31/2 hours of leisure per weekday - spent mostly with television, radio, newspapers, or magazines - they can expect over 51/2 hours of leisure per Sunday (see Table 2). Unlike weekdays, on Sundays there is more of a balance between passive and active pursuits. On average, 3.0 hours are spent with the media and 2.7 hours are spent in more active enjoyments. The top active pursuits are hobbies (1.1 hours) and socializing (0.8 hours). Expected time playing sports is more than twice as great on Sundays than weekdays, but the Sunday average is still less than 22 minutes (0.36 hours).

Although males and females can expect similar amounts of weekday free time, on Sundays men enjoy roughly two hours more leisure than women. The extra two hours are evenly split: men spend extra an hour in media activities and an extra hour in more active pursuits. Moreover, for each category of active leisure men average more time than women.

\section{Factors Affecting Leisure Activities: Specification}

It looks as if men experience more leisure than women, at least on Sundays. How does expected free time vary with conditions of working life? To estimate this relationship with the observations in the sample, I specified the following linear regression model:

Leisure time per Weekday (Sunday) $=\beta_{0}+\beta_{1}$ Age $+\beta_{2} A g e^{2}+$

$\beta_{3}$ Work experience $+\beta_{4}(\text { Work experience })^{2}+$

$\beta_{5}$ Scheduled work hours $+\beta_{6}$ Non-scheduled work hours +

$\beta_{7}$ Monthly contractual earnings $+\beta_{8}$ Annual bonus +

$\beta_{9} L$ abor force participation rate $+\beta_{10}$ Unemployment rate

$\beta_{11}$ Female $+\beta_{12}$ Year $96+\varepsilon$.

The first four explanatory variables reflect age and average duration of labor service. As 
workers age and gain experience, they also are likely to gain more responsibilities, which could impinge on leisure time for middle-aged employees. As workers reach the pinnacle of their careers, enjoying some privileges of seniority, perhaps they can afford more leisure time. If these presumptions are correct, we would expect $\beta_{1}<0$ and $\beta_{2}>0, \beta_{3}<0$ and $\beta_{4}>0$.

If scheduling more hours of work per month impinges on leisure, then $\beta_{5}<0$. If extra hours of work are added beyond those regularly scheduled, leisure time may be squeezed, meaning $\beta_{6}<0$.

All regular employees in Japan have one-year labor contracts, which stipulate monthly contractual pay. If leisure is a normal good, it should vary directly with monthly contractual pay, meaning $\beta_{7}>0$.

Employees also receive semi-annual bonuses, which are determined at their employers' discretion. Bonuses can be relatively large, equal to several months' regular pay, but they are transitory. Bonus payments are calibrated for seniority, with more experienced workers receiving bigger bonuses than their junior colleagues. Suppose employees must work longer hours to earn bigger bonuses, then $\beta_{8}<0$. But if employees use their transitory bonuses to finance leisure activities, $\beta_{8}>0$ would be observed.

Labor market conditions should affect peoples' free time. The higher is the labor force participation rate for a group of persons, the greater should be time spent working, meaning less free time, $\beta_{9}<0$. Unemployment also should affect leisure time. A higher unemployment rate among a group of persons could mean more idleness, and thus, more time for leisure, $\beta_{10}>0$; of course, unemployment could mean lost income, and thus, reduced means to enjoy leisure, $\beta_{10}<0$.

Table 2 suggests that there is a gender gap for leisure, at least for Sunday leisure. Female is a $0-1$ indicator variable (= 1 for the 48 female groups). If, other things equal, women enjoy less leisure time than men, $\beta_{11}<0$.

The Japanese government has exhorted companies to reduce working hours and 
encourage more holidays from work. If people have started to live a more leisure-oriented lifestyle, we should observe more time spent in leisure activities for the latter observations (1996 and 2001) than the former ones (1986 and 1991). Year 96 is a $0-1$ indicator variable (= 1 for the latter 48 observations, 1996 and 2001). If a more leisure-oriented lifestyle has developed, other things equal, then $\beta_{12}>0$.

Table 3 presents descriptive statistics for the various explanatory variables. Among the different age cells, average duration of work service is 10.0 years, with men averaging 2.2 years more work experience than women. The mean for regularly scheduled work hours per month is 173.5, with little difference between males and females. In contrast, men average $14^{2} / 3$ hours of extra work per month compared to $61 \frac{1}{2}$ hours for women.

For monthly contractual earnings the mean is $¥ 230,690$, with men earning nearly $11 \frac{1}{2}$ times more than women. The gender gap is even wider for bonuses, with men collecting a yearly bonus of $¥ 931,850$ and women averaging only $¥ 543,890$.

Labor force participation also exhibits a noticeable gender gap. Whereas nearly threefourths of men participate in the labor market, only one-half of women supply labor. Males do exhibit higher unemployment rates than females, 4.5 percent versus 3.9 percent.

\section{Factors Affecting Weekday Leisure: Results}

Focusing first on weekdays, I used equation (1) to estimate how expected weekday leisure time is related to working life. The regression results are presented in Table 4 (left column). ${ }^{7}$ As expected, weekday leisure time is inversely related with work experience, but the negative impact of experience wanes over time.

Regularly scheduled work hours significantly impinge on weekday leisure. Ten extra hours of work per month reduce expected leisure by 0.23 hours per weekday (roughly 14 minutes); assuming twenty-five weekdays days per month, that's 5.75 hours of lost leisure per month. More non-scheduled work time also cuts into free time. Ten extra hours of work per 
month reduce expected weekday leisure by nearly 0.14 hours (8.2 minutes per day, or 3.4 hours per month). In contrast, free time during the week is unrelated either to regular pay or bonuses.

As expected, more work time means less weekday leisure time. Also it is no surprise that labor force participation means less free time; although significant, the impact is small.

Unemployment means more idleness, which results in slightly more time spent pursuing leisure activities.

The figures reported in Table 1 suggest that men and women enjoy similar amounts of weekday leisure time. But that near-parity could be exaggerated because females are less likely to work and working women spend fewer hours on the job. The regression coefficients in Table 4 show that there is a substantial gender gap for weekday leisure. Controlling for working life conditions, women experience significantly less weekday free time than men. Being female, other things equal, means 0.66 fewer hours of daily leisure (40 minutes daily, 16 hours monthly).

The Japanese government announced an objective of reaching by 1996 a target of 150 regularly scheduled working hours per month, thereby permitting people to pursue a more leisure-oriented lifestyle. Table 3 reports that scheduled monthly hours average 173.5 for the whole sample. For the first half of the sample (1986 and 1991), scheduled hours average 178.2; for the second half (1996 and 2001) the average does indeed fall, albeit only to 168.9 hours. Furthermore, non-scheduled hours fall from 11.2 to 9.9. These developments do indeed contribute to leisure time.

Working hours aside, have the Japanese become more leisure-oriented? Other things equal, for 1996 and 2001 Japanese adults experienced no more weekday leisure than for 1986 and 1991. A more leisurely lifestyle appears to be elusive, at least for weekdays.

The figures reported in Table 1 show that media activities dominate leisure time. Excluding media activities, are the other, more active, types of leisure similarly related to work variables? To answer this question, I re-estimated the weekday leisure equation, excluding 
expected time spent in media activities. The regression results are presented in Table 4 (right column) ${ }^{8}$

Excluding media activities, weekday leisure time is still related to work experience. Similarly, free time is inversely related to scheduled work time and labor force participation; it is directly related to unemployment. When it comes to the more active types of leisure, women still have significantly less time than men. But once the more passive media activities are excluded, there are some meaningful differences.

The drive to encourage more free-time has not been conspicuously successful. For 1996 and 2001, other things equal, there is less active leisure time than for the earlier years. According to the estimated coefficient, active leisure falls 0.12 hours per weekday ( 7 minutes), which amounts to three lost hours per month. Because overall leisure is not affected substantially, the implication is that in recent years Japanese people have substituted activities like watching television and reading magazines for more active forms of amusement.

Overall, weekday leisure suffers as overtime work is increased. But active leisure is unaffected by non-scheduled work. Extra work cuts into weekday media time, but not more outgoing pursuits.

The more active types of leisure are also related to income. Workers in higher earning groups can expect more weekday time for active pursuits. An extra $¥ 100,000$ in regular monthly pay means an extra quarter-hour of active leisure per weekday, that is, an extra 61/4 hours per month. Evidently, higher earning groups substitute more outgoing pursuits for passive, mediaoriented enjoyment.

Transitory income, in contrast, discourages the more outgoing leisure pursuits. Groups earning bigger bonuses tend to take less weekday leisure. An extra $¥ 100,000$ per year in bonus pay means 5 fewer minutes of active leisure per weekday, that is, 2 hours per month. For an extra $¥ 100,000$ bonus in a year, workers sacrifice 24 hours of active weekday leisure. 


\section{Factors Affecting Sunday Leisure: Results}

Given the results for weekday leisure, are there similar findings for Sundays? Using equation (1), I estimated how expected Sunday leisure time is related to working life. The regression results are presented in Table 5, with overall leisure in the left column and active leisure in the right column. ${ }^{9}$

In some respects, the results for Sundays are similar to those for weekdays. Leisure is U-shaped with respect to age and experience, at first declining and then increasing.

There is a leisure gender gap on Sundays as well as weekdays. Other things equal, on Sundays women enjoy 1.35 fewer hours (80 minutes) of free time than men. Not counting media activities, the leisure gap is 0.9 hours (54 minutes).

In other key respects Sunday leisure is different than during the week. For weekdays, leisure is negatively related to labor force participation but positively related to unemployment. In contrast, Sunday leisure is positively influenced by labor force participation and unaffected by unemployment. As people become more likely to work, they are also more likely to enjoy free time on traditionally work-free Sundays. Because Sundays are usually work-free anyway, leisurely pursuits are unaffected by the idleness of unemployment.

Regularly scheduled work hours cut into all types of weekday leisure, but not all types of Sunday enjoyments. An increase in regular work time does not curtail Sunday leisure, but people do substitute passive media activities for more active recreation.

In response to unscheduled extra work hours, weekday leisure suffers because media activities are curtailed. When people experience extra work hours, on Sundays they sacrifice media time and replace it with more active amusements.

Weekday leisure is unaffected by regular earnings, but higher earners do increase active enjoyments, like hobbies or socializing, at the expense of watching television or reading newspapers or magazines. On Sundays, however, higher earners do enjoy more spare time and 
they spend it on media activities. An extra $¥ 100,000$ in regular monthly pay means an extra hour every Sunday with television, radio, newspapers, or magazines.

Bonus pay inhibits active leisure during the week. Focusing on Sundays, bonus pay stifles all types of leisure. An extra $¥ 100,000$ for the yearly bonus means a loss of 7 minutes of Sunday leisure; over the course of a year, that's about $5 \frac{1}{2} 2$ hours of lost enjoyment. Adding that $5 \frac{1}{2} 2$ hours lost on Sundays to the 24 hours lost during weekdays, an extra $¥ 100,000$ bonus costs a worker nearly 30 hours a year of lost leisure.

Has Japanese society become more leisure-oriented than before, at least on Sundays? In 1996 and 2001 Japanese adults enjoyed roughly 15 minutes less active leisure per Sunday than in 1991 and 1986, with that time being replaced with more media activities. Adding the 15 minutes lost each Sunday to the 7 minutes lost each weekday, Japanese adults substitute nearly 1 hour per week of passive media activities for more active pastimes. In recent years Japan has not cultivated a more outgoing leisure lifestyle.

\section{Summary and Conclusions}

Has “workaholic” Japan become a more leisure-oriented society? The evidence is mixed. Controlling for labor market factors, Japanese adults have not in recent years come to experience more leisure time overall. They have increased their time spent - one hour per week - in passive, media activities like watching television, listening to radio, and reading newspapers or magazines. This increase, however, has come at the expense of more outgoing amusements like hobbies, sports, or socializing.

There is a significant gender gap for leisure time. Other things equal, women experience significantly less free time than men: 0.66 fewer free hours than men per weekday (40 minutes per weekday), 1.35 fewer hours per Sunday (about 1 hour, 20 minutes).

Leisure is U-shaped over the life cycle, at first falling with age and work experience and 
then rising. Not surprisingly, working time impinges on leisure. Overtime work cuts into media activities but does not diminish more active amusements (like hobbies, socializing, or playing sports). Cutting 10 hours from the monthly work schedule, other things equal, means an extra 45 minutes per week for outgoing leisure. So shortening regular work schedules should encourage a more active leisure lifestyle.

Leisurely pursuits are also influenced by income. Leisure is directly related to regular monthly earnings. Specifically, higher contractual pay encourages more active leisure pursuits during the week and more media entertainment on Sundays. Leisure may be encouraged by regular income, but it is stifled by bonus pay. An extra $¥ 100,000$ yearly bonus costs a person roughly 30 hours of lost leisure time during the year.

Given these findings, how can Japan cultivate a more leisure-oriented lifestyle? Japanese policy makers should recognize that adults have been substituting passive, media-oriented entertainment at the expense of more outgoing, strenuous pastimes. If the objective is to encourage more leisure, especially active pursuits, then policies to cut regular working hours or de-emphasize the role of bonuses in total income may be needed. Efforts also should be aimed at women, who enjoy substantially less free time than men. 


\section{References}

Leheny, David. 2003. The Rules of Play: National Identity and the Shaping of Japanese Leisure. Ithaca: Cornell University Press.

_ . 2000. “'By Other Means’: Tourism and Leisure as Politics in Pre-War Japan.” Social Science Japan Journal 3 (October): 171-186.

Linhart, Sepp. 1988. “From Industrial to Postindustrial Society: Changes in Japanese LeisureRelated Values and Behavior.” Journal of Japanese Studies 14 (Summer): 271-307.

Linhart, Sepp and Sabine Frühstück, editors. 1998. The Culture of Japan as Seen through Its Leisure. Albany: State University of New York Press.

McCormack, Gavan. 1996. The Emptiness of Japanese Affluence. Armonk, NY: M.E. Sharpe. Plath, David W., editor. 1983. Work and Lifecourse in Japan. Albany: State University of New York Press.

. 1964. The After Hours: Modern Japan and the Search for Enjoyment. Berkeley: University of California Press. 


\section{Endnotes}

1. For background on the pursuit of leisure in Japan, see the seminal study by Plath (1964). More recent studies include Linhart (1988) and the collection edited by Linhart and Frühstück (1998).

2. For background on leisure policies, also see Leheny (2000) and McCormack (1996).

3. The enumeration districts are used in conducting Japan's regular (five-yearly) census of the population.

4. Results from the "Time Use" surveys are reported in the Japan Statistical Yearbook. For details, see the appendix.

5. Figures for working time are reported in the Year Book of Labour Statistics. For details, see the appendix.

6. For teenage males - likewise females - I merged work results for the “ $<17$ ” group with the leisure data for the “15-19” group; similarly, work data for the “18-19” group are merged with leisure figures for the “15-19” group. I merged work and leisure data for the “20-24”, “25-29”, “30-34” . ., “50-54”, “55-59”, and “60-64” groups. For the “65+” work group, I used leisure observations for the “65-69” group.

7. According to White's test (no cross-terms), the null hypothesis of homoskedasticity can be rejected at the five percent level (F-statistic: 2.147). Thus, the least squares regression is estimated using White's heteroskedasticity-consistent standard errors and covariance.

8. Once media activities are excluded, White's test (no cross-terms) cannot reject the null hypothesis of homoskedasticity at the five percent level (F-statistic: 1.12). Thus, the equation is estimated using ordinary least squares. 
9. For the case of overall leisure, White's test (no cross-terms) shows that the null hypothesis of homoskedasticity can be rejected (F-statistic: 1.869). The regression is estimated using White's heteroskedasticity-consistent standard errors and covariance. For active leisure (leisure excluding media activities), the White test indicates that homoskedasticity can be rejected (F-statistic: 1.789$)$. So the regression is estimated using White's heteroskedasticity-consistent standard errors and covariance. 


\section{Appendix}

Time Use Data. Time use data are available in the Japan Statistical Yearbook (published in Tokyo by the government's Statistics Bureau), in the table entitled “Time Spent per Day on Leisure Activities and Participation Rate by Age Group and Day of the Week.” The 2001 figures come from the 2004 Yearbook; the 1996 data are from the 2001 Yearbook; the 1991 data are from the 1997 Yearbook; the 1986 figures are from the 1992 Yearbook.

Working Life Data. Working life data can be found in the Year Book of Labour Statistics (published in Tokyo by the government's Ministry of Labour). Specifically, observations for 2001 are in the 2001 Year Book; similarly, data for 1996, 1991, and 1986 are from the 1996, 1991, and 1986 Year Books, respectively. For 1986 the observations come from the table entitled “Average Age, Duration of Service, Monthly Hours Worked, Monthly Contractual Cash Earnings and Annual Special Cash Earnings, and Estimated Number of Employees by Industrial Group, Size of Enterprise, and Type of Regular Employees, Sex and Age.” For 1991, 1996, and 2001 the table is entitled “Average Age, Length of Service, Number of Working Hours, Contractual Cash Earnings, Scheduled Earnings and Special Cash Payments

and Number of Employees, by Industry, Size of Enterprise, Sex, Type of Regular Employees and Age Group.”

Unemployment figures are from the Year Book of Labour Statistics. Observations for 2002 are from the 2001 Year Book; data for 1996, 1991, and 1986 are from the 1998, 1994, and 1990 Year Books, respectively. The figures are from the table entitled "Population Aged 15 and over by Labour Force Status, Sex, and Age Group.” 
Table 1

Expected Leisure Time per Weekday:

Mean (Standard Deviation)

\begin{tabular}{|c|c|c|c|c|}
\hline \multicolumn{2}{|c|}{$\begin{array}{l}\text { Expected number of hours spent } \\
\text { on a weekday on: }\end{array}$} & $\begin{array}{l}\text { Men and Women } \\
\text { Combined }\end{array}$ & Men & Women \\
\hline \multicolumn{2}{|c|}{ Leisure activities overall } & $\begin{array}{l}3.42 \\
(0.71)\end{array}$ & $\begin{array}{c}3.51 \\
(0.86)\end{array}$ & $\begin{array}{l}3.34 \\
(0.52)\end{array}$ \\
\hline Passive leisure: & Media & $\begin{array}{l}2.13 \\
(0.50)\end{array}$ & $\begin{array}{c}2.16 \\
(0.57)\end{array}$ & $\begin{array}{l}2.10 \\
(0.43)\end{array}$ \\
\hline \multirow[t]{6}{*}{ Active leisure: } & All activities & $\begin{array}{l}1.29 \\
(0.46)\end{array}$ & $\begin{array}{c}1.34 \\
(0.53)\end{array}$ & $\begin{array}{l}1.23 \\
(0.37)\end{array}$ \\
\hline & Hobbies & $\begin{array}{c}0.48 \\
(0.18)\end{array}$ & $\begin{array}{c}0.51 \\
(0.22)\end{array}$ & $\begin{array}{l}0.45 \\
(0.11)\end{array}$ \\
\hline & Socializing & $\begin{array}{c}0.37 \\
(0.09)\end{array}$ & $\begin{array}{c}0.37 \\
(0.10)\end{array}$ & $\begin{array}{c}0.37 \\
(0.08)\end{array}$ \\
\hline & Playing sports & $\begin{array}{c}0.15 \\
(0.11)\end{array}$ & $\begin{array}{c}0.18 \\
(0.13)\end{array}$ & $\begin{array}{c}0.12 \\
(0.08)\end{array}$ \\
\hline & $\begin{array}{l}\text { Study for self- } \\
\text { improvement }\end{array}$ & $\begin{array}{c}0.24 \\
(0.25)\end{array}$ & $\begin{array}{c}0.24 \\
(0.24)\end{array}$ & $\begin{array}{c}0.24 \\
(0.26)\end{array}$ \\
\hline & $\begin{array}{l}\text { Volunteering, } \\
\text { social causes }\end{array}$ & $\begin{array}{c}0.05 \\
(0.03)\end{array}$ & $\begin{array}{c}0.04 \\
(0.03)\end{array}$ & $\begin{array}{c}0.05 \\
(0.03)\end{array}$ \\
\hline
\end{tabular}


Table 2

Expected Leisure Time per Sunday: Mean (Standard Deviation)

\begin{tabular}{|c|c|c|c|c|}
\hline \multicolumn{2}{|c|}{$\begin{array}{l}\text { Expected number of hours spent } \\
\text { on a Sunday on: }\end{array}$} & $\begin{array}{l}\text { Men and Women } \\
\text { Combined }\end{array}$ & Men & Women \\
\hline \multicolumn{2}{|c|}{ Leisure activities overall } & $\begin{array}{l}5.69 \\
(1.15)\end{array}$ & $\begin{array}{l}6.65 \\
(0.47)\end{array}$ & $\begin{array}{l}4.72 \\
(0.74)\end{array}$ \\
\hline Passive leisure: & Media & $\begin{array}{l}3.00 \\
(0.60)\end{array}$ & $\begin{array}{l}3.46 \\
(0.42)\end{array}$ & $\begin{array}{l}2.55 \\
(0.35)\end{array}$ \\
\hline \multirow[t]{6}{*}{ Active leisure: } & All activities & $\begin{array}{l}2.68 \\
(0.79)\end{array}$ & $\begin{array}{l}3.19 \\
(0.61)\end{array}$ & $\begin{array}{l}2.18 \\
(0.60)\end{array}$ \\
\hline & Hobbies & $\begin{array}{c}1.11 \\
(0.33)\end{array}$ & $\begin{array}{l}1.40 \\
(0.15)\end{array}$ & $\begin{array}{l}0.82 \\
(0.14)\end{array}$ \\
\hline & Socializing & $\begin{array}{c}0.83 \\
(0.31)\end{array}$ & $\begin{array}{c}0.88 \\
(0.33)\end{array}$ & $\begin{array}{l}0.77 \\
(0.28)\end{array}$ \\
\hline & Playing sports & $\begin{array}{l}0.36 \\
(0.17)\end{array}$ & $\begin{array}{c}0.49 \\
(0.12)\end{array}$ & $\begin{array}{c}0.24 \\
(0.10)\end{array}$ \\
\hline & $\begin{array}{l}\text { Study for self- } \\
\text { improvement }\end{array}$ & $\begin{array}{l}0.26 \\
(0.25)\end{array}$ & $\begin{array}{c}0.29 \\
(0.23)\end{array}$ & $\begin{array}{c}0.24 \\
(0.27)\end{array}$ \\
\hline & $\begin{array}{l}\text { Volunteering, } \\
\text { social causes }\end{array}$ & $\begin{array}{l}0.12 \\
(0.07)\end{array}$ & $\begin{array}{c}0.13 \\
(0.07)\end{array}$ & $\begin{array}{c}0.11 \\
(0.06)\end{array}$ \\
\hline
\end{tabular}


Table 3

Factors Affecting Expected Leisure Time:

Descriptive Statistics

Mean (Standard Deviation)

\begin{tabular}{lccc}
\hline Explanatory variable & Men and Women & & \\
& Combined & Men & Women \\
\hline & 40.55 & 40.58 & 40.53 \\
$\begin{array}{l}\text { Age } \\
\text { (years, average per age group) }\end{array}$ & $(16.72)$ & $(16.78)$ & $(16.84)$ \\
Work experience & 10.01 & 11.18 & 8.84 \\
(average years per age group) & $(6.38)$ & $(7.27)$ & $(5.17)$ \\
& 173.54 & 174.19 & 172.90 \\
$\begin{array}{l}\text { Scheduled work hours } \\
\text { (regular monthly hours, average per age group) }\end{array}$ & $(6.40)$ & $(6.09)$ & $(6.69)$ \\
$\begin{array}{l}\text { Non-scheduled work hours } \\
\text { (extra hours per month, average per age group) }\end{array}$ & 10.56 & 14.67 & 6.46 \\
& $(5.84)$ & $(5.60)$ & $(1.80)$ \\
$\begin{array}{l}\text { Monthly contractual earnings } \\
\text { (thousands of ¥, average per age group) }\end{array}$ & 230.69 & 275.13 & 186.24 \\
& $(82.89)$ & $(91.76)$ & $(37.84)$ \\
$\begin{array}{l}\text { Annual bonus } \\
\text { (thousands of ¥, average per age group) }\end{array}$ & 737.87 & 931.85 & 543.89 \\
& $(453.23)$ & $(534.98)$ & $(228.33)$ \\
$\begin{array}{l}\text { Labor-force participation rate } \\
\text { (percentage, average per age group) }\end{array}$ & 62.45 & 74.51 & 50.40 \\
$\begin{array}{l}\text { Unemployment rate } \\
\text { (percentage, average per age group) }\end{array}$ & $(29.22)$ & $(30.90)$ & $(21.78)$ \\
\hline
\end{tabular}


Table 4

Factors Affecting Expected Leisure Time per Weekday

\begin{tabular}{|c|c|c|}
\hline Dependent variable & $\begin{array}{l}\text { Expected leisure time } \\
\text { per weekday }\end{array}$ & $\begin{array}{l}\text { Expected leisure time } \\
\text { per weekday } \\
\text { (excluding } \\
\text { “media” activities) }\end{array}$ \\
\hline $\begin{array}{l}\text { Explanatory } \\
\text { variable }\end{array}$ & $\begin{array}{l}\text { Estimated coefficient } \\
\qquad(t \text {-statistic })\end{array}$ & $\begin{array}{l}\text { Estimated coefficient } \\
\quad(t \text {-statistic })\end{array}$ \\
\hline Constant & $\begin{array}{l}8.7097 * * \\
(8.015)\end{array}$ & $\begin{array}{l}3.9339 * * \\
(4.368)\end{array}$ \\
\hline $\begin{array}{l}\text { Age } \\
\text { (years, average per age group) }\end{array}$ & $\begin{array}{l}-0.0243 \\
(-1.145)\end{array}$ & $\begin{array}{r}-0.0102 \\
(-0.589)\end{array}$ \\
\hline Age $^{2}$ & $\begin{array}{l}0.0008 * * \\
(4.092)\end{array}$ & $\begin{array}{r}0.0002 \\
(0.902)\end{array}$ \\
\hline $\begin{array}{l}\text { Work experience } \\
\text { (average years per age group) }\end{array}$ & $\begin{array}{l}-0.1205^{* *} \\
(-2.658)\end{array}$ & $\begin{array}{l}-0.0601 * * \\
(-2.060)\end{array}$ \\
\hline Work experience $^{2}$ & $\begin{array}{l}0.0026^{* *} \\
(2.013)\end{array}$ & $\begin{array}{l}0.0021^{* *} \\
(2.694)\end{array}$ \\
\hline $\begin{array}{l}\text { Scheduled work hours } \\
\text { (regular monthly hours, average per age group) }\end{array}$ & $\begin{array}{l}-0.0232 * * \\
(-4.341)\end{array}$ & $\begin{array}{l}-0.0106^{* *} \\
(-2.436)\end{array}$ \\
\hline $\begin{array}{l}\text { Non-scheduled work hours } \\
\text { (extra hours per month, average per age group) }\end{array}$ & $\begin{array}{l}-0.0136 * * \\
(-2.580)\end{array}$ & $\begin{array}{c}0.0018 \\
(0.399)\end{array}$ \\
\hline $\begin{array}{l}\text { Monthly contractual earnings } \\
\text { (thousands of } ¥ \text {, average per age group) }\end{array}$ & $\begin{array}{r}0.0005 \\
(0.320)\end{array}$ & $\begin{array}{l}0.0025^{* *} \\
(1.994)\end{array}$ \\
\hline $\begin{array}{l}\text { Annual bonus } \\
\text { (thousands of } ¥ \text {, average per age group) }\end{array}$ & $\begin{array}{l}-0.0005 \\
(-1.550)\end{array}$ & $\begin{array}{l}-0.0008^{* *} \\
(-3.389)\end{array}$ \\
\hline $\begin{array}{l}\text { Labor-force participation rate } \\
\text { (percentage, average per age group) }\end{array}$ & $\begin{array}{l}-0.0049 * * \\
(-2.724)\end{array}$ & $\begin{array}{l}-0.0045^{* *} \\
(-3.491)\end{array}$ \\
\hline $\begin{array}{l}\text { Unemployment rate } \\
\text { (percentage, average per age group) }\end{array}$ & $\begin{array}{l}0.0266^{*} \\
(1.668)\end{array}$ & $\begin{array}{l}0.0277^{* *} \\
(3.016)\end{array}$ \\
\hline $\begin{array}{l}\text { Female } \\
\text { ( } 1 \text { if female group; } 0 \text { if male) }\end{array}$ & $\begin{array}{l}-0.6565^{* *} \\
(-7.363)\end{array}$ & $\begin{array}{l}-0.2853^{* *} \\
(-3.747)\end{array}$ \\
\hline $\begin{array}{l}\text { Year } 96 \\
\text { (1 if } 1996 \text { or later; } 0 \text { if before } 1996)\end{array}$ & $\begin{array}{l}-0.0961 \\
(-1.439)\end{array}$ & $\begin{array}{l}-0.1217 * * \\
(-2.378)\end{array}$ \\
\hline
\end{tabular}


Table 4 (continued)

Factors Affecting Expected Leisure Time per Weekday

\begin{tabular}{lcc}
\hline Dependent variable & $\begin{array}{c}\text { Expected Leisure Time } \\
\text { per weekday }\end{array}$ & $\begin{array}{c}\text { Expected Leisure Time } \\
\text { per weekday } \\
\text { (excluding } \\
\text { "Media” Activities) }\end{array}$ \\
\hline $\mathrm{R}^{2}$ & 0.953 & 0.940 \\
$\begin{array}{l}\text { F-statistic } \\
\text { (overall regression) }\end{array}$ & $141.649 * *$ & $107.552^{* *}$ \\
Number of groups & 96 & 96 \\
\hline
\end{tabular}

**Significant at the 5 percent level; *Significant at the 10 percent level. 
Table 5

Factors Affecting Expected Leisure Time per Sunday

\begin{tabular}{|c|c|c|}
\hline Dependent variable & $\begin{array}{l}\text { Expected leisure time } \\
\text { per Sunday }\end{array}$ & $\begin{array}{l}\text { Expected leisure time } \\
\text { per Sunday } \\
\text { (excluding } \\
\text { “media” activities) }\end{array}$ \\
\hline $\begin{array}{l}\text { Explanatory } \\
\text { variable }\end{array}$ & $\begin{array}{l}\text { Estimated coefficient } \\
\quad(t \text {-statistic })\end{array}$ & $\begin{array}{l}\text { Estimated coefficient } \\
\quad(t \text {-statistic })\end{array}$ \\
\hline Constant & $\begin{array}{l}8.7320^{* *} \\
(5.945)\end{array}$ & $\begin{array}{l}8.2065^{* *} \\
(6.984)\end{array}$ \\
\hline $\begin{array}{l}\text { Age } \\
\text { (years, average per age group) }\end{array}$ & $\begin{array}{l}-0.1876^{* *} \\
(-6.856)\end{array}$ & $\begin{array}{l}-0.1001^{* *} \\
(-4.645)\end{array}$ \\
\hline Age $^{2}$ & $\begin{array}{l}0.0021^{* *} \\
(7.972)\end{array}$ & $\begin{array}{l}0.0009 * * \\
(4.322)\end{array}$ \\
\hline $\begin{array}{l}\text { Work experience } \\
\text { (average years per age group) }\end{array}$ & $\begin{array}{l}-0.1290 * * \\
(-2.416)\end{array}$ & $\begin{array}{l}-0.0551 \\
(-1.414)\end{array}$ \\
\hline Work experience $^{2}$ & $\begin{array}{l}0.0047 * * \\
(3.025)\end{array}$ & $\begin{array}{l}0.0033^{* *} \\
(2.843)\end{array}$ \\
\hline $\begin{array}{l}\text { Scheduled work hours } \\
\text { (regular monthly hours, average per age group) }\end{array}$ & $\begin{array}{l}0.0016 \\
(0.216)\end{array}$ & $\begin{array}{c}-0.0157 * * \\
(-\end{array}$ \\
\hline $\begin{array}{l}\text { Non-scheduled work hours } \\
\text { (extra hours per month, average per age group) }\end{array}$ & $\begin{array}{r}0.0067 \\
(1.128)\end{array}$ & $\begin{array}{l}0.0110 * \\
(1.690)\end{array}$ \\
\hline $\begin{array}{l}\text { Monthly contractual earnings } \\
\text { (thousands of } ¥ \text {, average per age group) }\end{array}$ & $\begin{array}{l}0.0097 * * \\
(4.334)\end{array}$ & $\begin{array}{r}0.0031 \\
(1.568)\end{array}$ \\
\hline $\begin{array}{l}\text { Annual bonus } \\
\text { (thousands of } ¥ \text {, average per age group) }\end{array}$ & $\begin{array}{l}-0.0013^{* *} \\
(-2.744)\end{array}$ & $\begin{array}{l}-0.0011^{* *} \\
(-2.825)\end{array}$ \\
\hline $\begin{array}{l}\text { Labor-force participation rate } \\
\text { (percentage, average per age group) }\end{array}$ & $\begin{array}{l}0.0053 * * \\
(2.073)\end{array}$ & $\begin{array}{l}0.0049 * * \\
(2.398)\end{array}$ \\
\hline $\begin{array}{l}\text { Unemployment rate } \\
\text { (percentage, average per age group) }\end{array}$ & $\begin{array}{l}-0.0163 \\
(-0.804)\end{array}$ & $\begin{array}{l}-0.0086 \\
(-0.640)\end{array}$ \\
\hline $\begin{array}{l}\text { Female } \\
\text { ( } 1 \text { if female group; } 0 \text { if male) }\end{array}$ & $\begin{array}{l}-1.3512^{* *} \\
(-12.709)\end{array}$ & $\begin{array}{l}-0.8957 * * \\
(-10.998)\end{array}$ \\
\hline $\begin{array}{l}\text { Year } 96 \\
\text { (1 if } 1996 \text { or later; } 0 \text { if before } 1996)\end{array}$ & $\begin{array}{l}-0.1497 \\
(-1.607)\end{array}$ & $\begin{array}{l}-0.2411^{* *} \\
(-3.582)\end{array}$ \\
\hline
\end{tabular}


Table 5 (continued)

Factors Affecting Expected Leisure Time per Sunday

\begin{tabular}{lcc}
\hline Dependent variable & $\begin{array}{c}\text { Expected Leisure Time } \\
\text { per Sunday }\end{array}$ & $\begin{array}{c}\text { Expected Leisure Time } \\
\text { per Sunday } \\
\text { (excluding } \\
\text { "Media” Activities) }\end{array}$ \\
\hline $\mathrm{R}^{2}$ & 0.966 & 0.954 \\
$\begin{array}{l}\text { F-statistic } \\
\text { (overall regression) }\end{array}$ & $196.155^{* *}$ & $164.839 * *$ \\
Number of groups & 96 & 96 \\
\hline
\end{tabular}

**Significant at the 5 percent level; *Significant at the 10 percent level. 